Article

\title{
Systems Engineering for the Energy Transition: Potential Contributions and Limitations
}

\author{
Arjan Kirkels ${ }^{1}$ * , Vince Evers ${ }^{1}$ and Gerrit Muller ${ }^{2, *}$ D \\ 1 School of Innovation Sciences, Eindhoven University of Technology, 5612 AE Eindhoven, The Netherlands; \\ v.h.m.evers@student.tue.nl \\ 2 Faculty of Technology, Natural Sciences and Maritime Sciences, Campus Kongsberg, \\ University of South-Eastern Norway, 3613 Kongsberg, Norway \\ * Correspondence: a.f.kirkels@tue.nl (A.K.); gerrit.muller@usn.no (G.M.)
}

Citation: Kirkels, A.; Evers, V.; Muller, G. Systems Engineering for the Energy Transition: Potential Contributions and Limitations. Sustainability 2021, 13, 5423. https://doi.org/10.3390/su13105423

Academic Editor: Cecilia Haskins

Received: 30 March 2021

Accepted: 10 May 2021

Published: 12 May 2021

Publisher's Note: MDPI stays neutral with regard to jurisdictional claims in published maps and institutional affiliations.

Copyright: (c) 2021 by the authors. Licensee MDPI, Basel, Switzerland. This article is an open access article distributed under the terms and conditions of the Creative Commons Attribution (CC BY) license (https:/ / creativecommons.org/licenses/by/ $4.0 /)$.

\begin{abstract}
Systems engineering finds its origin in analyzing and exploring complicated technical systems. In this positioning paper, we set out to discuss the value and limitations of a Systems Engineering approach in its contribution to societal challenges, notably the energy transition. We conceptualize the energy system as a sociotechnical system. We specifically explore stakeholders and their roles, agency, and acceptance. We illustrate the relevance by a case at the municipal level that shows the relevance of acceptance, pluralism, distributed agency, context, and process aspects. The municipality is still in a phase of exploration and conceptualization. Systems Engineering can be of great value in this phase to explore the problem and solution space. However, to make the most of this requires that Systems Engineering addresses policy making, distributed agency, and complexity. We discuss the challenges this poses for the traditional Systems Engineering approach; we indicate several potential strategies to address these challenges, and we show two fields that can help clarify how to address these challenges: transition studies and sustainability assessment.
\end{abstract}

Keywords: systems engineering; energy transition; renewable energy; sociotechnical system; stakeholders; agency; acceptance; complex problems; transition studies; sustainability assessment

\section{Introduction}

Energy drives all activities and is strongly related to prosperity, production, consumption, and well-being [1-4]. As such, a good energy supply is crucial for achieving many sustainable development goals (SDGs) [2], and an urgent call for action is needed to ensure peace and prosperity for people and the planet, now and in the future [5,6]. Especially SDG 7 targets the energy supply: "Ensure access to affordable, reliable, sustainable and modern energy for all" $[5,6]$.

Achieving the goals as stated in SDG 7 requires a transition, a radical shift in the energy system [1], from a fossil fuel-based system to one based on renewable energy sources. Especially in developed countries, reducing greenhouse gas emissions is a crucial driver behind recent developments in the energy sector $[7,8]$. The complexity, scale, and urgency of the required transition make it one of the grand societal challenges for the 21 st century. Over the last few decades, this problem has received increased attention in academic [9-11] and policy circles [12-14].

The energy supply has all characteristics of a system: primary energy sources are mined in nature and are converted by an apparatus to secondary energy sources, which in turn are converted to energy services. All elements are interconnected by infrastructure and transport [15]. Traditionally, System Engineering has had substantial contributions to the sector, with a specific focus on understanding and assessing the techno-economic feasibility of these engineered systems [16]. In addition, for the future, there is a significant potential for contributions from the field of Systems Engineering, given the enormous changes required for the energy transition. 
However, traditionally, Systems Engineering has been focused on exploring and analyzing technical systems and complicated problems. Although that is a valuable contribution by itself, we will argue in this positioning paper that the energy transition, and societal challenges in general, require a different approach. In essence, by their nature, energy systems are sociotechnical systems. These systems include infrastructure and conversion technology and markets, cultural aspects, regulatory paradigms, and consumer behavior $[1,15,17]$. As such, they require unpacking socioeconomic factors, including stakeholders' roles, normativity, and agency. These are issues that are hardly addressed by traditional Systems Engineering that would rather see normativity and agency either as clients' goals and customers' needs and requirements or as contextual factors for the engineering system. In the traditional approach, normative and agency aspects are typically addressed in a rather instrumental and technocratic way, focusing on how to model or how to manage [18-20].

Discussions and developments in the energy transition show that many struggles to embrace and accelerate the energy transition relate to the sociotechnical nature of the transition. One challenge is translating the generally accepted policy goals into specific roadmaps, action plans, and policy approaches. These serve to align stakeholders' interests and visions, empower stakeholders, and build up momentum to build up a robust approach However, change invokes resistance. With the recently increased diffusion and (larger scale) implementation of solar PV and onshore wind, the acceptance of renewables has become a prominent issue [21-30] that can severely affect the support and direction of the energy transition.

In summary, we conceptualized the energy system as a sociotechnical system in transition. Our goal for this positioning paper was to indicate the relevance of Systems Engineering approaches, to illustrate the problems that arise due to the misfit with sociotechnical systems, to discuss strategies to overcome that misfit, and to indicate related fields from which lessons can be learned. As such, we contributed to the goal of this special issue to focus on Systems Engineering's role in contributing to grand societal challenges and providing policy advice [16,31].

We specifically focused on the diversity of stakeholders, their roles, and their agency, including societal acceptance issues. To do so, we drew upon an illustrative case study on the heating transition for the small city of Best in the Netherlands. This approach is analytically helpful as it reduces complexity: Goals, boundaries, and involved stakeholders can be clearly identified, dynamics can be easily understood. Over recent years, Dutch municipalities have been assigned a more substantial role in the energy transition, e.g., by making local plans for the heat transition in the built environment and specifying local potential [32]. However, municipalities typically lack experience and expertise in this field and struggle with questions about a regional energy transition [33,34]. The city of Best is especially relevant as it committed itself to far-reaching goals [35-37]; there is an active energy cooperative, Duurzaam Best, indicating a willingness to act among citizens; but despite this, a project to implement a heating network in the Naastenbest neighborhood recently failed $[38,39]$. As such, it provides an excellent illustrative case to study both stakeholders and broad aspects of acceptance. Finally, a systems architecting study had already been conducted for Best [40,41], which offered some prior knowledge.

In the next paragraph, we introduce sociotechnical systems and acceptance concepts more thoroughly based on relevant literature. Next, in the methodology section, we discuss the approach for the illustrative case, followed by the empirical results. Finally, we present a conclusion and discussion on the potential for contribution and the challenges in Systems Engineering and how to overcome these challenges.

\section{Sociotechnical Systems and Acceptance}

We argue that complex societal problems, such as the energy transition, require a sociotechnical system approach. A sociotechnical system has been introduced and developed in the field of science and technology studies (STS). A sociotechnical system has been 
defined as "a configuration of technologies, services, and infrastructures, regulations, and actors (for example, producers, suppliers, policymakers, users) that fulfills a societal function" [42]. It assumes that a broader set of stakeholders is involved in developing and implementing technology and that the social and technical aspects co-evolve. It builds on the notion of a coupled development of technology with social practices, rules, and normative settings $[15,17,43]$; the distributed agency over a variety of stakeholders and moments, i.e., the capacity to act and influence [44]; and the complexity of the problems, characterized by normative pluralism, inherent uncertainty, and emerging behavior [45-47]. As such, a broad set of stakeholders is relevant as are their roles, preferences, practices, and processes of interaction and decision-making. Relevant issues in this field include justice, public engagement, social construction, expectations, transforming innovations, and governing complex transitions [48]. A traditional limited stakeholder analysis focusing on power and interest will not cover all these aspects.

Recently the energy transition started to take shape. It moved from an idea or concept to an actual realization by implementing, among other things, larger scale solar PV and onshore wind. Consequently, the impact and hindrance of these technologies became clear and started to affect more extensive groups of stakeholders. The lack of social acceptance of renewables has become a prominent issue [21-30] that can severely affect the support and direction of the energy transition.

Acceptance, or the lack thereof, is a typical example of sociotechnical aspects of the energy transition. Acceptance is a broad concept that can refer to people's ability to "tolerate", "regard something as inevitable", or "approve of something or to encourage it". It can manifest itself as attitudes and actions on a spectrum of involvement and agency, i.e., the capacity to make choices [21,49]. Other crucial questions are who is accepting and what is being accepted. When it comes to social acceptance, Wüstenhagen et al. [29] differentiate between sociopolitical, market, and community acceptance: Sociopolitical acceptance refers to the acceptance of general goals, technologies, and policies by the public, key stakeholders, and policymakers. Market acceptance relates to the adoption and diffusion of innovations in the market by companies, consumers, and investors. Finally, community acceptance refers to residents' and local stakeholders' acceptance in siting decisions and renewable energy projects. This differentiation can help to increase understanding. For example, the not in my backyard (NIMBY) phenomenon that is seriously hampering the local energy transition $[22,23,25,30]$ is a combination of large sociopolitical acceptance with low community acceptance.

The three types of acceptance as identified by Wüstenhagen et al. are influenced by five key factors related to the stakeholders involved and local factors, as determined from the literature (see Figure 1): financial costs and benefits; values and goals; justice and participation; trust and communication; and efficacy and reasibility. Financial costs and benefits refer to the initial investment, the payback time, and the expected return on investment. Low investment costs, short payback times, and a reduction of monthly energy costs are considered critical preconditions for community acceptance. Simultaneously, a solid business case is more decisive for market and sociopolitical acceptance [50-52].

Values and goals refer to an individual's preferences based on personal norms, values, motivations, and goals. When the intended effects of sustainable measures are perceived to align with these values and goals, the actions are more likely to be considered favorably [53]. Common goals influencing community acceptance are the improvement of public health, the stimulation of (economic and scientific) advancement, and the creation of moral and caring communities $[50,53]$, as well as safety, autonomy to choose, little hindrance, a comfortable living environment, and preservation of the natural environment [51]. 


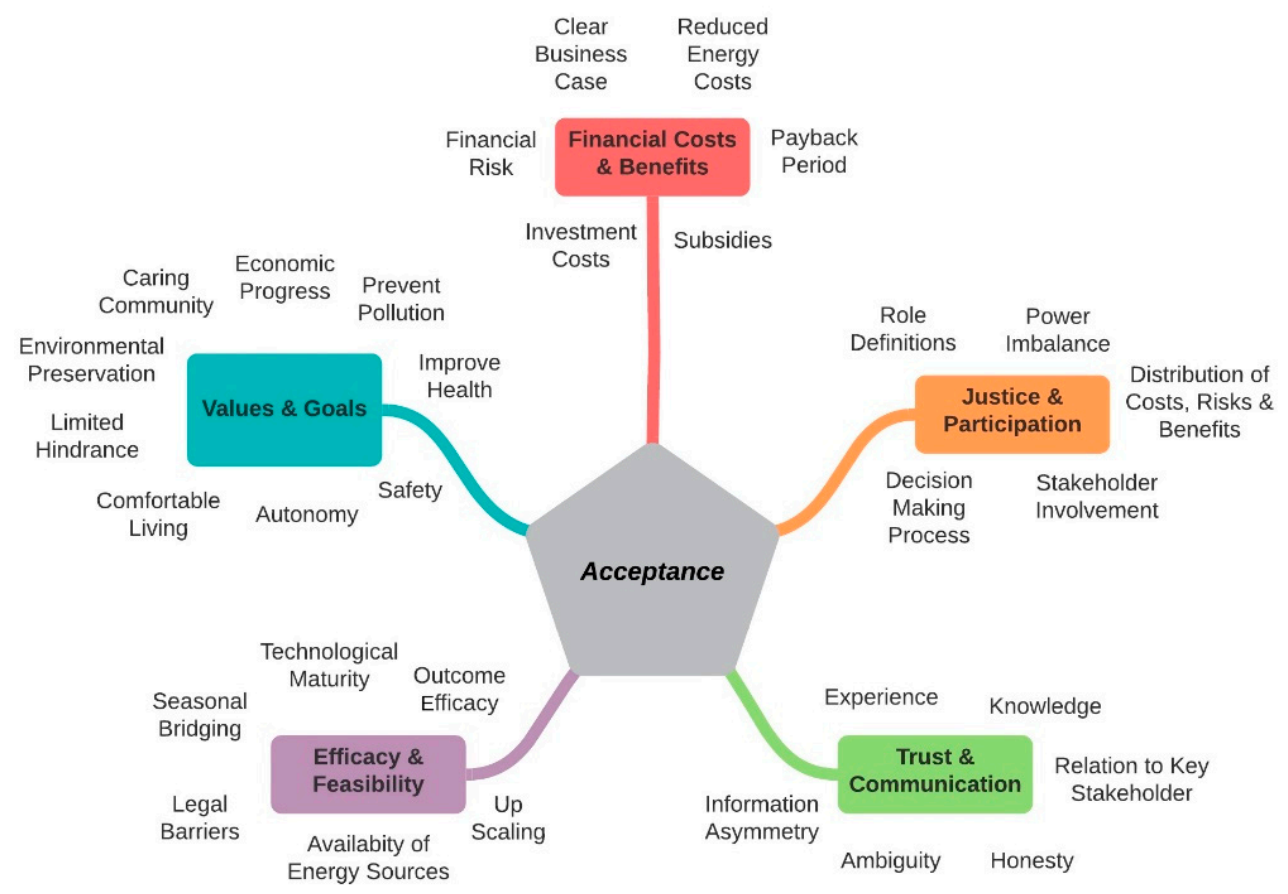

Figure 1. Conceptual map of key concepts affecting different types of acceptance.

Justice and participation both relate to the process of decision-making. Distributional justice relates to a perceived (im)balance in the distribution of costs, benefits, and risks among critical stakeholders. Procedural injustice is often experienced as a result of a perceived imbalance of power [23]. A perceived lack of justice and participation can result in damaged stakeholder relations and opposition $[29,50,54]$. As such, it is especially relevant for community acceptance and sociopolitical acceptance.

Trust and communication both relate to the stakeholders involved and their interaction. When knowledge of sustainable measures and technologies is limited, community acceptance depends on trust in experts and decision-makers $[23,24,29,30,50]$. As such, sociopolitical acceptance (or lack thereof) may trickle down to community acceptance. Trust is shown to affect acceptance most strongly through information relating to costs, benefits, and risks. Ambiguous or dishonest communication negatively affects trust in responsible stakeholders and increases perceived injustice. The importance of trust is also well described in other literature, e.g., in business [55,56], in governance [57-59], and for new large and risky technologies $[60,61]$. We argue that it is crucial for all three forms of acceptance. Due to recent developments, trust issues have become even more critical (e.g., due to individualism, alternative facts, distrust of central governments, and the role of social media) $[62,63]$.

Finally, the efficacy and feasibility of proposed measures are essential. Individuals are less accepting if an action is considered unrealistic or when the effect of implementation on a final goal (outcome efficacy) is considered small [30]. Questions of feasibility are often related to technological maturity, the availability of energy sources, the matching of supply and demand of energy, the scalability, and the ownership of proposed solutions [52,64].

The more recent literature on acceptance is more critical and elaborates further on the justice and participation aspect. It primarily focuses on injustices and inequalities, and as such, aligns more with an STS agenda. It concentrates on the role of time and history in the energy transition, adopts a more relational framework (studying the production and consumption side and local and national level at the same time), takes into consideration power relationships (e.g., the relationship between expert political and lay systems), and the role of sociopolitical contexts. It moves away from positivist and individual frameworks towards the analysis of socially constructed discourses [65]. 


\section{Methodology}

We set out to explore stakeholders involved, their roles, and the issue of (social) acceptance for the case of Best, more specifically for the failed Naastenbest project. We studied directly involved key stakeholders to understand better their roles, the sociopolitical context, the process, and the differences and tensions between the political, expert, and lay systems. In addition, we studied the social acceptance of the local public and how that was affected by different factors.

The most relevant (directly involved, influential) stakeholders in the Naastenbest project were identified by the initial study of academic and grey literature and preliminary interviews. The municipal council has the formal responsibility for the energy transition in the municipality. The municipal officials support this council. The housing cooperation owns and builds rental houses as a delegated government responsibility and is especially relevant for initiatives in the built environment, as was the case for the Naastenbest project. Installation companies play a central role in engineering and installing energy and heating infrastructure and equipment. Best Duurzaam is an association of citizens who strive for sustainability. It engages with the societal debate and local initiatives.

In the next step, semi-structured interviews were held with each of these stakeholders. This approach matches the research's explorative nature and the level of involvement of the stakeholders [49]. Probing questions are employed to elicit additional information on potentially sensitive topics, assist respondents in recalling the information, and explore issues that were not previously identified as relevant [66]. Based on selective sampling, 32 stakeholders were approached, of which 10 agreed to the interview, covering all five relevant stakeholder groups, see Table 1. Interviews were conducted over the phone or by Skype (due to COVID-19 restrictions), following an open interview guide. Interviews typically lasted $45-75 \mathrm{~min}$. Interviews were not recorded but notes were taken. Anonymized results were analyzed to identify key concepts and themes.

Table 1. Selective sampling of relevant stakeholder groups.

\begin{tabular}{cc}
\hline Stakeholder & \# Interviewed \\
\hline Municipality of Best & 1 \\
\hline Municipal Council & 2 \\
\hline Energy cooperation “Duurzaam Best” & 4 \\
\hline Housing cooperation & 1 \\
\hline Installation company & 1 \\
\hline
\end{tabular}

Finally, social acceptance in the community was assessed by an online survey that focused on broader acceptance of energy measures and policies. The survey consisted of closed questions and open questions (remarks) and was designed to assess (1) demographic characteristics of respondents; (2) the general attitude towards sustainability and the energy transitions; (3) perceived drivers and barriers for taking action; (4) the role of the municipality; and (5) the support for concrete measures, either individually or at the municipal level. Respondents were approached on multiple online platforms to increase the response rate and reduce potential sampling bias. These platforms included 'Plein Best' and 'Groeiend Best', as well as Facebook communities such as 'Best voor Best' and 'Best anders'. Moreover, fourteen area representatives were contacted to spread the survey among residents in their neighborhoods. In total, this resulted in 85 respondents.

\section{Results of the Illustrative Case}

In February 2020, officials of the Municipality of Best, responsible for the energy transition in Best, submitted a proposal for a district heating network including seasonal storage. This project targeted several national subsidies for the exploration of heating options. For the planning, the municipality cooperated with an installation company. The 
prospected users included a sports hall, a few schools, private individuals, and, most notably, tenants of the local social housing corporations. Members of Best Duurzaam, the local energy cooperative, reviewed and supported this proposal, albeit conditionally. Ultimately, the municipal council rejected the proposal later that year. Both the interviews and surveys were held after the rejection.

\subsection{The District Heating Naastenbest Project}

Differences in stakeholders' values and goals resulted in varying attitudes towards sustainability and district heating in Best. Both Best Duurzaam and the municipality were motivated by (inter)national climate goals (5 respondents), either intrinsically (Best Duurzaam) or by pragmatic political motivations (municipality). Members of the municipal council (2) stressed the importance of aligning their goals with their political party's program. The housing corporation and the installation company (2) were mainly motivated by the prospect of future financial gains. Most stakeholders (7) raised concerns about the technological feasibility with respect to the location of the system (3), the scalability of the distribution network (3), and the seasonal balance between generated and stored energy (1). Additional concerns were raised about uncertainty and the distribution between stakeholders of financial costs and benefits, e.g., uncertainties regarding (exploitation) costs and subsidies (5), unclarity on ownership of the network (3), uncertainty regarding (the potential for) upscaling and future financial returns (2), and doubts on the long-term risks of operation (4). Most stakeholders (8) acknowledged the importance of stakeholder participation and justice but were not satisfied with the participation process in the Naastenbest project (6). Both Best Duurzaam (4) and the municipal council (2) believe that they were inadequately involved in the decision-making process, as key information was shared too late. This strongly contributed to the discontinuation of the Naastenbest project. Most of the interviewees (6) partly attributed doubts and critiques to unclear communication by the municipality. A lack of trust among stakeholders was not explicitly mentioned, but frequently implied (6) through the questions that were raised concerning the municipal alderman's perceived lack of effort in passing the proposal (5), the trustworthiness of commercial stakeholders (3), and the involvement of the energy cooperative Best Duurzaam (3). An additional issue was the lack of vision and policy (8). Most stakeholders (7) indicated the absence of an overarching long-term vision on the energy transition at the municipal level. Long-term prospects are missing (2) and follow-up actions are undefined (2), making it hard to judge the strategic relevance of this project. In addition, a more precise definition of stakeholder roles was considered crucial for sound policy making (7). Opinions on the merit of the district heating proposal varied widely among stakeholders. Best Duurzaam members (4) indicated they were favorable towards the design despite their publicly expressed concerns. In contrast, the municipal council members (2) were less optimistic and expressed concerns that the (long-term) risks were not transparently and sufficiently covered.

\subsection{Acceptance among Residents of Best}

Overall, the survey revealed a variety of responses per question, indicating that the group is heterogenous: Different people have different drivers, preferences, and experience various barriers. There is broad support for sustainability and energy-saving measures within the sample. Many inhabitants have taken feasible and straightforward actions, such as insulation (over half) and domestic solar PV (about half), or are thinking of implementing them. Personal drivers are both pragmatic and value-based, e.g., saving money, improving comfort, reducing the impact on climate change, and protecting the environment are indicated to be relevant, as well as belief in progress and morality of choice. Community aspects (community connection, social obligation) are not perceived as relevant drivers. For many participants, previous bad experiences, lack of favorable financing, risks, and climate critique were not barriers for further implementation. Some concerns were raised with respect to costs and their contribution. More large-scale, intrusive, novel, expensive, 
or contested technologies received less support, e.g., heat pumps, electric vehicles, solar collectors for implementation by residents, solar farms, biomass power plants, wind turbines, and district heating by the municipality. Only the application of PV panels on public buildings received broad support. Most participants were neutral on the role and activities of the municipality. However, in the open questions, there was strong criticism. In particular, unclarity of information, lack of participation, and distrust towards the municipality were mentioned. Another frequently mentioned topic was the potential risk of large-scale projects on the environment.

\section{Conclusions and Discussion}

\subsection{Lessons from the Case}

Our primary interest was in exploring the diversity of stakeholders, their roles, and the acceptance of renewable energy as an illustrative case for the social struggles that affect the energy transition. The literature review shows that acceptance is a broad concept that manifests itself as attitudes and actions on a spectrum of agency and involvement. Acceptance also depends on who is accepting and what is being accepted. The literature differentiates between sociopolitical, market, and community acceptance. Different factors influence these types of acceptance: financial costs and benefits; values and goals; justice and participation; trust and communication; and efficacy and feasibility. In addition, they are affected by issues of power and sociopolitical context and are visible in and affected by socially constructed discourses.

Overall, the interviews showed the distributed agency in the Naastenbest project: Several stakeholders were involved in the process by steering, influencing, decision making, and acting over an extended period and in a sometimes ill-defined project. The lack of clear data and analysis were generally shared concerns among stakeholders, e.g., on technical and financial feasibility and the distribution of cost and benefits. Process aspects strengthened these concerns: the lack of clear communication, issues of good governance and participatory approaches, ambiguity in the process, stakeholder roles, and alignment with broader societal and transition goals. Most stakeholders are supportive towards addressing climate change (sociopolitical acceptance), but at the same time, are supportive of many other goals. It is not clear how stakeholders deal with trade-offs; or how to come to an approach that does justice to all stakeholders involved, clarifies their roles, and results in a shared agenda. An overarching long-term vision of achieving the energy transition on the municipal level (either focused on actions or process and roles) is lacking. This lack of a long-term vision hinders short-term decision making and an integrated assessment of the feasibility and potential contribution of the project. Representatives of the municipality see the pilot project as experimentation, which can be an excellent strategy to overcome complexity if it results in increased visioning, networking, and learning within the community and broader stakeholder groups $[11,67]$. In this specific case, this contribution was disputed by several stakeholders. Trust was a sensitive topic, especially considering the disagreement on goals and roles and the failed project.

The survey on community acceptance showed the heterogeneity of the group: different people have different drivers, preferences, and experience other barriers. Overall, there is broad support for sustainability and energy-saving measures. Many inhabitants are taking or are willing to take measures, especially feasible and straightforward measures such as insulation and solar PV installation. More large-scale, intrusive, novel, expensive, or contested technologies received less support. Expressed concerns included unclarity of information, lack of participation, and distrust towards the municipality.

The survey was distributed over multiple channels, resulting in residents' participation from all neighborhoods. Still, some districts, house owners, older people, and members of the energy cooperative were overrepresented. However, we feel that these issues have not seriously hampered our conclusions, as we aimed for exploratory research on an illustrative case. We think that an even more representative sample could have revealed more diversity and more considerable differences in goals, context, and preferences. 


\subsection{Systems Engineering of Sociotechnical Systems}

The case revealed that the municipality is still in a phase of exploration and conceptualization of the problem and potential solutions. We argue that Systems Engineering can be of great value $[16,31,68]$; it offers a straightforward and well traceable approach, in which the problem space is made explicit, and the solution space is explored. It evaluates technologies for their potential contribution to foreseen systems, and it does so in a consistent way. It can help to make sense of possible solutions and can clarify the roadmap of how to get there. It helps to focus the decision making and discussion on real issues by identifying (lack of) potential contribution to the overall goals. It can help prevent a focus on only short-term actions that receive a lot of support.

In particular, the last argument seemed to be relevant to the case of Best. Politics is an opportunistic process, which looks for mandate by the community and support and acceptance by stakeholders involved, strategically acting by creating and using societal momentum. However, that approach only results in short-term and feasible actions, the win-win solutions. However, addressing climate change requires disruptive change, a fundamental change in the energy system and its underlying driving forces. The uneasy message that there is no silver bullet, no simple solution that will solve all problems and be beneficial to all is hardly heard in politics. The energy transition requires profound, fundamental changes: reinvestment, rebuilding, redefining winners and losers of the system, upscaling of renewable energy technologies, and at some point might require intense system interventions, e.g., the out-phasing of specific technologies, products, or energy carriers [43,69-71]. Systems thinking is critical to understanding the inertia of the current sociotechnical system [72], to understanding the need for change in underlying driving forces, feedback mechanisms, and paradigms [69,73], and for exploring coherent alternative systems. Systems Engineering might be of great value in this process [16,74-77] to ensure that final goals are anchored in solid policy-making.

The case also reveals several characteristics that can be challenging for a traditional Systems Engineering approach. There is not one decision-maker, and stakeholders' needs and requirements are diverse and fuzzy. Instead, several stakeholders are involved: companies, governments, consumers, citizens, NGOs. They are characterized by different roles and behavior, different interests, all of which are context dependent. That diversity is visible between and within stakeholder groups (e.g., citizens' preferences). It results in pluralism, multiple and sometimes conflicting views on problems, potential solutions, and the preferred process. Second, all these stakeholders have different levels of agency, the power to steer, decide, and influence. This agency is not only distributed over stakeholders but also over time. It makes sense making, goal setting, decision making, and steering a matter of processes, rather than discrete decision-making moments. Third, the involvement of stakeholders and agency results in socialware in addition to the traditional technology hardware, i.e., norms, rules, regulations, and practices that are an inherent part of the system. Social scientists talk of sociotechnical systems to indicate the intimate interdependencies and influences of the social and technical. The socioeconomic part is no longer considered the context of a technical system, but rather becomes an inherent part of that system. This has major consequences for how to conceptualize and analyze these systems. Finally, the behavior of this system is complex, resulting in inherent uncertainties. These are the results of the pluralism and agency by stakeholders and the many interactions between all sociotechnical elements and between systems (systems-of-systems), resulting in emerging behavior.

We argue that to understand or predict system behavior and to be of more value for decision making and governance, the traditional Systems Engineering approach needs to be adapted. Here, we indicate some potential strategies. Note that several of these strategies are non-exclusive and can be combined. First, introduce pluralism by taking into account multiple viewpoints or applying sensitivity analysis. Second, operationalize sociotechnical systems, including diversity of stakeholders and distributed agency. Third, conduct participatory Systems Engineering, as is done in conceptual modeling. Stake- 
holders know best their preferences and viewpoints, and it offers possibilities for shared learning. Fourth, put less emphasis on the preferred action or technology and more on learning about the deep problem structure, system behavior, and solution spaces. This way, it offers second-order learning and empowerment of stakeholders involved. Fifth, put more emphasis on sufficient and resilient solutions, rather than on optimal solutions. Finally, look at the potential role of System Engineering studies as boundary objects: an object that ties together scientific knowledge and societal goals and values. As a boundary object, the outcome of a Systems Engineering study enters the social arena of governance, public debate, and decision making.

We realize that these are not topics that come naturally to the average Systems Engineer. Most of these strategies are not simple, e.g., looking at different system boundaries or doing an additional task. They require bridging between different worldviews and research paradigms, between positivist approaches present in engineering sciences and constrained relativist approaches of value for transition thinking, policy-making, and governance [78]. However, initial efforts are visible in the field to start engaging with these challenges [79], e.g., by addressing sociotechnical systems (e.g., [77,80-84]), stakeholders' goals and agency (e.g., [18,85]), complex systems and systems-of-systems (e.g., [86-89]), conceptual modelling (e.g., [90,91]), and systems thinking (e.g., [75,76,82,92]).

However, Systems Engineering does not have to start from scratch as it can draw upon and learn from closely related fields $[68,93,94]$. Especially, the field of transition studies seems relevant. It builds on sociotechnical systems to understand and potentially influence transitions and diffusion of sustainable innovations. Its starting points are co-evolution of sociotechnical systems; multi-actor processes; embracing uncertainty and complexity; values and pluralism; normative directionality; and a focus on stability and change $[9,10]$. As such, it has a significant conceptual and theoretical contribution. However, in the field there is less focus on quantitative approaches and assessment [74], which offers room for contributions by Systems Engineering.

A second relevant field is sustainability assessment. It shares with Systems Engineering a strong focus on methodology, quantification, systems, and technology, which might be helpful as both fields speak the same language. However, the field seems to be ahead in addressing complex problem solving and being of policy relevance, e.g., by broadening of scope ([95-102]) to clarify the ambivalent and disputed concept of sustainability and assess it in all its dimensions; by strategic future orientation and dealing with uncertainties ([101-108]); by participative approaches and dealing with stakeholders, normative aspects, and plurality $([107,109-115]) ;$ by analyzing how assessments can support policymaking and governance $([78,106,114,116-119])$; and by increasing reflexivity and making the normative basis of assessments explicit ([78,101,102,117,120]).

\section{Final Conclusions}

We set out to discuss the value and limitations of a Systems Engineering approach for contributing to societal challenges, in particular the energy transition. We did so by approaching the energy system as a sociotechnical system. We unpack the stakeholders' roles, agency, and acceptance in the case of the Naastenbest project in Best. It revealed the pluralism between and within stakeholder groups, the distributed agency, the relevance of trust and decision-making processes, and the context-dependency. Finally, we discussed the challenges this poses for the traditional Systems Engineering approach; we indicated several potential strategies to address these challenges; and identified two fields that can help clarify how to address these challenges: transition studies and sustainability assessment.

Author Contributions: A.K., Conceptualization; Formal analysis; Investigation; Writing-original draft; Writing-review and editing; Supervision. V.E., Conceptualization; Methodology; Formal analysis; Validation; Investigation; Resources; Data Curation; Writing-empirical chapters; Writingreview and editing; Visualization. G.M., Conceptualization; Formal analysis; Writing-review and editing; Supervision. All authors have read and agreed to the published version of the manuscript. 
Funding: This research received no external funding.

Institutional Review Board Statement: Not applicable.

Informed Consent Statement: Not applicable.

Data Availability Statement: Not applicable.

Acknowledgments: We would like to thank two anonymous reviewers for their constructive comments.

Conflicts of Interest: The authors declare no conflict of interest.

\section{References}

1. Singh, H.V.; Bocca, R.; Gomez, P.; Dahlke, S.; Bazilian, M. The energy transitions index: An analytic framework for understanding the evolving global energy system. Energy Strat. Rev. 2019, 26, 100382. [CrossRef]

2. Fonseca, L.M.; Domingues, J.P.; Dima, A.M. Mapping the Sustainable Development Goals Relationships. Sustainability 2020, 12, 3359. [CrossRef]

3. Anderson, D.; Coelho, S.T.; Doucet, G.; Freudenschuss-Reichl, I.; Jefferson, M.; Jochem, E.; Williams, R.H. World Energy Assessment Overview: 2004 Update; United Nations Development Programme: New York, NY, USA, 2004; ISBN 978-92-1-126167-7.

4. Goldemberg, J. World Energy Assessment. Energy and the Challenge of Sustainability; United Nations Development Programme: New York, NY, USA, 2000; ISBN 92-1-126126-0.

5. United Nations. The Sustainable Development Goals Report 2017; United Nations: New York, NY, USA, 2017; ISBN 978-92-1-101368-9.

6. United Nations; Department of Economic and Social Affairs. The 17 Sustainable Development Goals. Available online: https: //sdgs.un.org/goals (accessed on 5 May 2021).

7. $\quad$ IPCC. Summary for Policymakers; IPCC: Geneva, Switzerland, 2018; ISBN 978-92-9169-151-7.

8. United Nations/Framework Convention on Climate Change. Adoption of the Paris Agreement, 21st Conference of the Parties; Paris, France, 2015. Available online: https://unfccc.int/resource/docs/2015/cop21/eng/109r01.pdf (accessed on 5 May 2021).

9. Markard, J.; Raven, R.; Truffer, B. Sustainability transitions: An emerging field of research and its prospects. Res. Policy 2012, 41, 955-967. [CrossRef]

10. Köhler, J.; Geels, F.W.; Kern, F.; Markard, J.; Onsongo, E.; Wieczorek, A.; Alkemade, F.; Avelino, F.; Bergek, A.; Boons, F.; et al. An agenda for sustainability transitions research: State of the art and future directions. Environ. Innov. Soc. Transit. 2019, 31, 1-32. [CrossRef]

11. Sengers, F.; Wieczorek, A.J.; Raven, R. Experimenting for sustainability transitions: A systematic literature review. Technol. Forecast. Soc. Chang. 2019, 145, 153-164. [CrossRef]

12. International Renewable Energy Agency. REthinking Energy; International Renewable Energy Agency: Abu Dhabi, United Arab Emirates, 2017.

13. EC-European Commission. 2020 Report on the State of the Energy Union; EC-European Commission: Brussels, Belgium, 2020.

14. EC-European Commission. Renewable Energy Progress Report; EC-European Commission: Brussels, Belgium, 2020.

15. Bradford, T. Energy System: Technology, Economics, Markets, and Policy; MIT Press: Cambridge, MA, USA, 2018.

16. INCOSE. A World in Motion. Systems Engineering Vision 2025; INCOSE: San Diego, CA, USA, 2014.

17. Geels, F.W. From sectoral systems of innovation to socio-technical systems. Res. Policy 2004, 33, 897-920. [CrossRef]

18. Salado, A. A systems-theoretic articulation of stakeholder needs and system requirements. Syst. Eng. 2021, 24, 83-99. [CrossRef]

19. Kasser, J. 7.7.1 Getting the right requirements right. INCOSE Int. Symp. 2012, 22, 1005-1020. [CrossRef]

20. SEBoK Authors. Stakeholder Needs and Requirements. Available online: https: / /www.sebokwiki.org/w $/$ index.php?title= Stakeholder_Needs_and_Requirements\&oldid=59944 (accessed on 7 March 2021).

21. Batel, S.; Devine-Wright, P.; Tangeland, T. Social acceptance of low carbon energy and associated infrastructures: A critical discussion. Energy Policy 2013, 58, 1-5. [CrossRef]

22. Raven, R.; Mourik, R.R.; Feenstra, C.; Heiskanen, E. Modulating societal acceptance in new energy projects: Towards a toolkit methodology for project managers. Energy 2009, 34, 564-574. [CrossRef]

23. Perlaviciute, G.; Steg, L. Contextual and psychological factors shaping evaluations and acceptability of energy alternatives: Integrated review and research agenda. Renew. Sustain. Energy Rev. 2014, 35, 361-381. [CrossRef]

24. Steg, L.; Perlaviciute, G.; Van Der Werff, E. Understanding the human dimensions of a sustainable energy transition. Front. Psychol. 2015, 6, 805. [CrossRef]

25. Segreto, M.; Principe, L.; Desormeaux, A.; Torre, M.; Tomassetti, L.; Tratzi, P.; Paolini, V.; Petracchini, F. Trends in Social Acceptance of Renewable Energy Across Europe-A Literature Review. Int. J. Environ. Res. Public Health 2020, 17, 9161. [CrossRef] [PubMed]

26. Seidl, R.; Von Wirth, T.; Krütli, P. Social acceptance of distributed energy systems in Swiss, German, and Austrian energy transitions. Energy Res. Soc. Sci. 2019, 54, 117-128. [CrossRef]

27. Sonnberger, M.; Ruddat, M. Local and socio-political acceptance of wind farms in Germany. Technol. Soc. 2017, 51, 56-65. [CrossRef]

28. Krick, E. Ensuring social acceptance of the energy transition. The German government's 'consensus management' strategy. J. Environ. Policy Plan. 2017, 20, 64-80. [CrossRef] 
29. Wüstenhagen, R.; Wolsink, M.; Bürer, M.J. Social acceptance of renewable energy innovation: An introduction to the concept. Energy Policy 2007, 35, 2683-2691. [CrossRef]

30. Heiskanen, E.; Hodson, M.; Mourik, R.M.; Raven, R.P.J.M.; Feenstra, C.F.J.; Torrent, A.A.; Brohmann, B.; Daniels, A.; Di Fiore, M.; Farkas, B.; et al. Factors Influencing the Societal Acceptance of New Energy Technologies: Meta-Analysis of Recent European Projects. 2008; ECN-E-07-058.

31. Sillitto, H.; Griego, R.; Arnold, E.; Dori, D.; Martin, J.; McKinney, D.; Godfrey, P.; Krob, D.; Jackson, S. A fresh look at Systems Engineering-What is it, how should it work? INCOSE Int. Symp. 2018, 28, 955-970. [CrossRef]

32. Rijksoverheid Klimaatakkoord. Klimaatakkoord. Den Haag. 2019. Available online: https://www.rijksoverheid.nl/documenten/ rapporten/2019/06/28/klimaatakkoord (accessed on 5 May 2021).

33. Hoppe, T.; Miedema, M. A Governance Approach to Regional Energy Transition: Meaning, Conceptualization and Practice. Sustainability 2020, 12, 915. [CrossRef]

34. Vringer, K.; De Vries, R.; Visser, H. Measuring governing capacity for the energy transition of Dutch municipalities. Energy Policy 2021, 149, 112002. [CrossRef]

35. Van Bergen, T.; Van Neerven, M.; Van Oosterhout, M. Beleidsplan Energie-en Materiaaltransitie. 2011. Available online: https:/ / repository.officiele-overheidspublicaties.nl/externebijlagen/exb-2019-24239/1/bijlage/exb-2019-24239.pdf (accessed on 5 May 2021).

36. Algra, C. Uitvoeringsprogramma Energietransitie 2017-2018. 2017. Available online: https:/ / decentrale.regelgeving.overheid.nl/ cvdr/xhtmloutput/Historie/Best/624284/CVDR624284_1.html (accessed on 5 May 2021).

37. Gemeente Best Samen aan de Slag met Duurzaam Wonen in Best. 2017. Available online: https://www.gemeentebest.nl/data/ downloadables/7/4/6/3/nota-samen-aan-de-slag-met-duurzaam-wonen-in-best.pdf (accessed on 5 May 2021).

38. Gemeenteraad Best. Raadsvoorstel: Duurzame Warmtevoorziening bij Reconstructie Naastenbest Aanleiding. 2020.

39. Gemeenteraad Best. Motie Gemeenteraad Best: Duurzame warmtevoorziening Naastenbest (20015) 09-03-2020. Available online: https:/ / best.notubiz.nl/modules/6/moties_en_toezeggingen/view (accessed on 5 May 2021).

40. Elvebakk, L.; Muller, G. Creating a Roadmap to Capture a Vision for a Sustainable Community in a Global Perspective: A Case Study in a Dutch Town Best. In Proceedings of the 29th INCOSE International Symposium, Orlando, FL, USA, $20-25$ July 2019.

41. Muller, G.; Elvebakk, L.; Van Der Velde, J.; Lean, F.M. Roadmapping for sustainability; How to navigate a social, political, and many systems-of-systems playing eld? A local initiative. In Proceedings of the 14th Annual Conference System of Systems Engineering, SoSE 2019, Anchorage, AK, USA, 19-22 May 2019; pp. 317-322.

42. Schot, J.; Kanger, L.; Verbong, G.G. The roles of users in shaping transitions to new energy systems. Nat. Energy 2016, 1, 16054. [CrossRef]

43. Köhler, J.; Geels, F.; Kern, F.; Onsongo, E.; Wieczorek, A.; Alkemaade, F.; Avelino, F.; Bergek, A.; Boons, F.; Bulkeley, H.; et al. A Research Agenda for the Sustainability Transitions Research Network. 2017. Available online: https://pure.tue.nl/ws/files/10128834 6/STRN_Research_Agenda_2017.pdf (accessed on 5 May 2021).

44. Moncada, J.A.; Lee, E.H.P.; Guerrero, G.N.; Okur, O.; Chakraborty, S.; Lukszo, Z. Complex Systems Engineering: Designing in sociotechnical systems for the energy transition. EAI Endorsed Trans. Energy Web 2017, 3, 152762. [CrossRef]

45. Rittel, H.W.J.; Webber, M.M. Dilemmas in a general theory of planning. Policy Sci. 1973, 4, 155-169. [CrossRef]

46. Probst, G.; Bassi, A.M. Tackling Complexity. A Systemic Approach for Decision Makers; Greenleaf Publishing: Sheffield, UK, 2014.

47. Kurtz, C.; Snowden, D. The new dynamics of strategy: Sense-making in a complex and complicated world. IEEE Eng. Manag. Rev. 2003, 31, 110. [CrossRef]

48. Sovacool, B.K.; Hess, D.J.; Amir, S.; Geels, F.W.; Hirsh, R.; Medina, L.R.; Miller, C.; Palavicino, C.A.; Phadke, R.; Ryghaug, M.; et al. Sociotechnical agendas: Reviewing future directions for energy and climate research. Energy Res. Soc. Sci. 2020, $70,101617$. [CrossRef]

49. Hisschemöller, M.; Midden, C.J.H. Improving the usability of research on the public perception of science and technology for policy-making. Public Underst. Sci. 1999, 8, 17-33. [CrossRef]

50. Huijts, N.M.A.; Molin, E.J.E.; Steg, L. Psychological factors influencing sustainable energy technology acceptance: A re-view-based comprehensive framework. Renew. Sustain. Energy Rev. 2012, 16, 525-531. [CrossRef]

51. Van Der Lelij, B.; De Graaf, M.; Visscher, J. Energievoorziening 2015-2050: Publieksonderzoek naar Draagvlak voor Verduurzaming van Energie; Ministry of Economic Affairs: Den Haag, The Netherlands, 2016; pp. 1-81.

52. PAW Rapportage Reflectieve Monitor 2019. Voortgang \& Leerervaringen. 2020. Available online: https://www.rijksoverheid. $\mathrm{nl}$ /binaries/rijksoverheid/documenten/rapporten/2020/01/22/voortgang-en-leerervaringen-27-proeftuinen-aardgasvrijewijken/rapportage-reflectieve-monitor-2019.pdf (accessed on 5 May 2021).

53. Bain, P.G.; Milfont, T.L.; Kashima, Y.; Bilewicz, M.; Doron, G.; Garðarsdóttir, R.B.; Gouveia, V.V.; Guan, Y.; Johansson, L.-O.; Pasquali, C.; et al. Co-benefits of addressing climate change can motivate action around the world. Nat. Clim. Chang. 2016, 6, 154-157. [CrossRef]

54. Lennon, B.; Dunphy, N.P.; Sanvicente, E. Community acceptability and the energy transition: A citizens' perspective. Energy Sustain. Soc. 2019, 9, 1-18. [CrossRef]

55. Blois, K.J. Trust in Business to Business Relationships: An Evaluation of its Status. J. Manag. Stud. 1999, 36, 197-215. [CrossRef]

56. Gounaris, S.P. Trust and commitment influences on customer retention: Insights from business-to-business services. J. Bus. Res. 2005, 58, 126-140. [CrossRef] 
57. Uslaner, E.M. Trust, Democracy and Governance: Can Government Policies Influence Generalized Trust? In Generating Social Capital; Springer: Berlin, Germany, 2003; pp. 171-190.

58. DiMaggio, P.; Braithwaite, V.; Levi, M. Trust and Governance. Contemp. Sociol. A J. Rev. 1999, 28, 731. [CrossRef]

59. Nye, J.S., Jr. In government we don't trust. Foreign Policy 1997, 99-111. [CrossRef]

60. Midden, C.J.H.; Huijts, N.M.A. The Role of Trust in the Affective Evaluation of Novel Risks: The Case of $\mathrm{CO}_{2}$ Storage. Risk Anal. 2009, 29, 743-751. [CrossRef] [PubMed]

61. Visschers, V.H.M.; Siegrist, M. How a Nuclear Power Plant Accident Influences Acceptance of Nuclear Power: Results of a Longitudinal Study Before and After the Fukushima Disaster. Risk Anal. 2012, 33, 333-347. [CrossRef] [PubMed]

62. Harrison, N.; Luckett, K. Experts, knowledge and criticality in the age of 'alternative facts': Re-examining the contribution of higher education. Teach. High. Educ. 2019, 24, 259-271. [CrossRef]

63. Newman, S. Post-truth and the crisis of the political. Soft Power 2019, 6, 90-108.

64. Westera, N. District Heating Ownership. Master's Thesis, Delft University of Technology, Delft, The Netherlands, 2018.

65. Batel, S. Research on the social acceptance of renewable energy technologies: Past, present and future. Energy Res. Soc. Sci. 2020, 68,101544 . [CrossRef]

66. Barriball, K.L.; While, A. Collecting data using a semi-structured interview: A discussion paper. J. Adv. Nurs. 1994, 19, 328-335. [CrossRef]

67. Smith, A.; Raven, R. What is protective space? Reconsidering niches in transitions to sustainability. Res. Policy 2012, 41, 1025-1036. [CrossRef]

68. Sataloff, R.T.; Johns, M.M.; Kost, K.M. Complex Systems. Breakthrough Innovations Through People. The H-SEIF Project Booklet; University of South-Eastern Norway: Notodden, Norway, 2020; ISBN 9781626239777.

69. Abson, D.J.; Fischer, J.; Leventon, J.; Newig, J.; Schomerus, T.; Vilsmaier, U.; Von Wehrden, H.; Abernethy, P.; Ives, C.D.; Jager, N.W.; et al. Leverage points for sustainability transformation. AMBIO 2017, 46, 30-39. [CrossRef]

70. Meadowcroft, J. What about the politics? Sustainable development, transition management, and long term energy transitions. Policy Sci. 2009, 42, 323-340. [CrossRef]

71. Fazey, I.; Schäpke, N.; Caniglia, G.; Patterson, J.; Hultman, J.; van Mierlo, B.; Säwe, F.; Wiek, A.; Wittmayer, J.; Aldunce, P.; et al Ten essentials for action-oriented and second order energy transitions, transformations and climate change research. Energy Res. Soc. Sci. 2018, 40, 54-70. [CrossRef]

72. Turnheim, B.; Geels, F.W. The destabilisation of existing regimes: Confronting a multi-dimensional framework with a case study of the British coal industry (1913-1967). Res. Policy 2013, 42, 1749-1767. [CrossRef]

73. Meadows, D. Leverage Points: Places to Intervene in a System; The Sustainability Institute: Hartland, VT, USA, 1999.

74. Holtz, G.; Alkemade, F.; de Haan, F.; Köhler, J.; Trutnevyte, E.; Luthe, T.; Halbe, J.; Papachristos, G.; Chappin, E.; Kwakkel, J.; et al. Prospects of modelling societal transitions: Position paper of an emerging community. Environ. Innov. Soc. Transit. 2015, 17, 41-58. [CrossRef]

75. Boardman, J.; Sauser, B. Systems Thinking: Coping with 21st Century Problems; CRC Press: Boca Raton, FL, USA, 2008.

76. Checkland, P. Systems Thinking, Systems Practice; John Wiley and Sons: New York, NY, USA, 1999.

77. Rechtin, E.; Maier, M.W. The Art of Systems Architecting; Apple Academic Press: Cambridge, MA, USA, 2010.

78. Tukker, A. Philosophy of science, policy sciences and the basis of decision support with LCA Based on the toxicity controversy in Sweden and the Netherlands. Int. J. Life Cycle Assess. 2000, 5, 177-186. [CrossRef]

79. Akeel, U.U.; Bell, S.J. Discourses of systems engineering. Eng. Stud. 2013, 5, 160-173. [CrossRef]

80. Kroes, P.; Franssen, M.; Van De Poel, I.; Ottens, M. Treating socio-technical systems as engineering systems: Some conceptual problems. Syst. Res. Behav. Sci. 2006, 23, 803-814. [CrossRef]

81. Ottens, M.; Franssen, M.; Kroes, P.; Van De Poel, I. 8.1.1 Systems engineering of socio-technical systems. INCOSE Int. Symp. 2005, 15, 1122-1130. [CrossRef]

82. Davis, M.C.; Challenger, R.; Jayewardene, D.N.; Clegg, C.W. Advancing socio-technical systems thinking: A call for bravery. Appl. Ergon. 2014, 45, 171-180. [CrossRef] [PubMed]

83. Davis, K.; Mazzuchi, T.; Sarkani, S. Architecting technology transitions: A sustainability-oriented sociotechnical approach. Syst. Eng. 2012, 16, 193-212. [CrossRef]

84. Haskins, C. Using patterns to transition systems engineering from a technological to social context. Syst. Eng. 2008, 11, 147-155. [CrossRef]

85. Wixom, B.H.; Todd, P.A. A Theoretical Integration of User Satisfaction and Technology Acceptance. Inf. Syst. Res. 2005, 16, 85-102. [CrossRef]

86. Poller, A. Exploring and managing the complexity of large infrastructure projects with network theory and model-based systems engineering-The example of radioactive waste disposal. Syst. Eng. 2020, 23, 443-459. [CrossRef]

87. Maier, M.W. Architecting Principles for Systems-of-Systems. Syst. Eng. 1999, 1, 267-284. [CrossRef]

88. Gorod, A.; Sauser, B.; Boardman, J. System-of-Systems Engineering Management: A Review of Modern History and a Path Forward. IEEE Syst. J. 2008, 2, 484-499. [CrossRef]

89. Boardman, J. System of Systems - the meaning of of. In Proceedings of the 2006 IEEE/SMC International Conference on System of Systems Engineering, Los Angeles, CA, USA, 24-26 April 2006; pp. 118-123. 
90. Neely, K.; Bortz, M.; Bice, S. Using collaborative conceptual modelling as a tool for transdisciplinarity. Evid. Policy A J. Res. Debate Pr. 2021, 17, 161-172. [CrossRef]

91. Newell, B.; Proust, K. Introduction to Collaborative Conceptual Modelling; Work. Pap. ANU Open Access Res.; 2012; p. 20. Available online: https:/ / digitalcollections.anu.edu.au/handle/1885/9386 (accessed on 5 May 2021).

92. Muller, G. Who Does the Societal Systems of Systems Thinking?

93. Geels, F.W.; Berkhout, F.; Van Vuuren, D.P. Bridging analytical approaches for low-carbon transitions. Nat. Clim. Chang. 2016, 6, 576-583. [CrossRef]

94. McDowall, W.; Geels, F.W. Ten challenges for computer models in transitions research: Commentary on Holtz et al. Environ. Innov. Soc. Transit. 2017, 22, 41-49. [CrossRef]

95. Jeswani, H.K.; Azapagic, A.; Schepelmann, P.; Ritthoff, M. Options for broadening and deepening the LCA approaches. J. Clean. Prod. 2010, 18, 120-127. [CrossRef]

96. Onat, N.C.; Kucukvar, M.; Halog, A.; Cloutier, S. Systems Thinking for Life Cycle Sustainability Assessment: A Review of Recent Developments, Applications, and Future Perspectives. Sustainability 2017, 9, 706. [CrossRef]

97. Dijk, M.; De Kraker, J.; Van Zeijl-Rozema, A.; Van Lente, H.; Beumer, C.; Beemsterboer, S.; Valkering, P. Sustainability assessment as problem structuring: Three typical ways. Sustain. Sci. 2017, 12, 305-317. [CrossRef] [PubMed]

98. Sala, S.; Farioli, F.; Zamagni, A. Progress in sustainability science: Lessons learnt from current methodologies for sustainability assessment: Part. Int. J. Life Cycle Assess. 2013, 18, 1653-1672. [CrossRef]

99. Sala, S.; Ciuffo, B.; Nijkamp, P. A systemic framework for sustainability assessment. Ecol. Econ. 2015, 119, 314-325. [CrossRef]

100. Gasparatos, A.; El-Haram, M.; Horner, M. A critical review of reductionist approaches for assessing the progress towards sustainability. Environ. Impact Assess. Rev. 2008, 28, 286-311. [CrossRef]

101. Reap, J.; Roman, F.; Duncan, S.; Bras, B. A survey of unresolved problems in life cycle assessment. Part 2: Impact assessment and interpretation. Int. J. Life Cycle Assess. 2008, 13, 374-388. [CrossRef]

102. Reap, J.; Roman, F.; Duncan, S.; Bras, B. A survey of unresolved problems in life cycle assessment. Part 1: Goal and scope and inventory analysis. Int. J. Life Cycle Assess. 2008, 13, 290-300. [CrossRef]

103. Arvidsson, R.; Tillman, A.; Sandén, B.A.; Janssen, M.; Nordelöf, A.; Kushnir, D.; Molander, S. Environmental Assessment of Emerging Technologies: Recommendations for Prospective LCA. J. Ind. Ecol. 2018, 22, 1286-1294. [CrossRef]

104. Waas, T.; Hugé, J.; Block, T.; Wright, T.; Benitez-Capistros, F.; Verbruggen, A. Sustainability Assessment and Indicators: Tools in a Decision-Making Strategy for Sustainable Development. Sustainability 2014, 6, 5512-5534. [CrossRef]

105. Beltran, A.M.; Cox, B.; Mutel, C.; Van Vuuren, D.P.; Vivanco, D.F.; Deetman, S.; Edelenbosch, O.Y.; Guinée, J.; Tukker, A. When the Background Matters: Using Scenarios from Integrated Assessment Models in Prospective Life Cycle Assessment. J. Ind. Ecol. 2020, 24, 64-79. [CrossRef]

106. Van Der Sluijs, J.P.; Petersen, A.C.; Janssen, P.H.M.; Risbey, J.S.; Ravetz, J.R. Exploring the quality of evidence for complex and contested policy decisions. Environ. Res. Lett. 2008, 3. [CrossRef]

107. Matthews, N.E.; Stamford, L.; Shapira, P. Aligning sustainability assessment with responsible research and innovation: Towards a framework for Constructive Sustainability Assessment. Sustain. Prod. Consum. 2019, 20, 58-73. [CrossRef] [PubMed]

108. Weidema, B.P.; Ekvall, T.; Pesonen, H.-L.; Rebitzer, G.; Sonnemann, G.W.; Spielmann, M. Scenarios in Life-Cycle Assessment; Society of Environmental Toxicology and Chemistry (SETAC): Pensacola FL, USA, 2004; ISBN 1-880611-57-0.

109. Reed, M.S. Stakeholder participation for environmental management: A literature review. Biol. Conserv. 2008, 141, $2417-2431$. [CrossRef]

110. Reed, M.; Fraser, E.D.G.; Morse, S.; Dougill, A.J. Integrating Methods for Developing Sustainability Indicators to Facilitate Learning and Action. Ecol. Soc. 2005, 10, 10. [CrossRef]

111. McCabe, A.; Halog, A. Exploring the potential of participatory systems thinking techniques in progressing SLCA. Int. J. Life Cycle Assess. 2016, 23, 739-750. [CrossRef]

112. Connelly, S. Mapping Sustainable Development as a Contested Concept. Local Environ. 2007, 12, 259-278. [CrossRef]

113. Scolobig, A.; Lilliestam, J. Comparing Approaches for the Integration of Stakeholder Perspectives in Environmental Decision Making. Resources 2016, 5, 37. [CrossRef]

114. Astleithner, F.; Hamedinger, A. The Analysis of Sustainability Indicators as Socially Constructed Policy Instruments: Benefits and challenges of 'interactive research'. Local Environ. 2003, 8, 627-640. [CrossRef]

115. Mathur, V.N.; Price, A.D.; Austin, S.A. Conceptualizing stakeholder engagement in the context of sustainability and its assessment. Constr. Manag. Econ. 2008, 26, 601-609. [CrossRef]

116. Seidel, C. The application of life cycle assessment to public policy development. Int. J. Life Cycle Assess. 2016, 21, 337-348. [CrossRef]

117. Holden, M. Sustainability indicator systems within urban governance: Usability analysis of sustainability indicator systems as boundary objects. Ecol. Indic. 2013, 32, 89-96. [CrossRef]

118. Holman, N. Incorporating local sustainability indicators into structures of local governance: A review of the literature. Local Environ. 2009, 14, 365-375. [CrossRef]

119. Hezri, A.A.; Dovers, S.R. Sustainability indicators, policy and governance: Issues for ecological economics. Ecol. Econ. 2006, 60, 86-99. [CrossRef]

120. Freidberg, S. From behind the curtain: Talking about values in LCA. Int. J. Life Cycle Assess. 2018, 23, 1410-1414. [CrossRef] 